КРИТЕРІЇ ТА ПОКАЗНИКИ СФОРМОВАНОСТІ ЕТНОКУЛЬТУРНОЇ КОМПЕТЕНТНОСТІ МАЙБУТНІХ УЧИТЕЛІВ МУЗИЧНОГО МИСТЕЦТВА

\title{
CRITERIA AND INDICATORS OF THE FORMATION OF FUTURE MUSIC ART TEACHERS' ETHNCULTURAL COMPETENCE
}

\begin{abstract}
У статті обгрунтовано змістове наповнення критеріїв і показників сорормованості етнокультурної компетентності майбутніх учителів музичного мистецтва. Зазначено, що мотиваційно-ціннісний критерій характеризується наявністю у майбутніх учителів музичного мистецтва прагнення до опанування професійними та етнокультурними знаннями, уміннями і навичками, що забезпечують подальщу успішну етнокультурну діяльність у практиці з учнівським колективом. Виділено основні показники цього критерію: бажання оволодіти етнокультурою, вміннями та навичками застосування нових зразків етнокультури; володіння етнокультурною компетентністю для самовдосконалення та самовираження у майбутній профресійній діяльності. Когнітивно-креативний критерій зумовлюе здатність майбутнього вчителя музичного мистецтва до творчого спілкування з етнокультурним мистецтвом, до глибоко індивідуального бачення художнього світу. Показники представленого критерію: повнота спеціальних знань: загальнокультурних і етнокультурних (особливостей, звичаїв, традичій, обрядів, вірувань, чінностей і переконань, схожості та розбіжностей у культурах різних етнорегіонах); сфрормованість етнокультурних якостей майбутніх учителів музичного мистецтва. Емоційно-рефрлексивний критерій характеризує сутнісну ознаку, що дає змогу виміряти емоційний складник педагогічного ефекту етнокультурної діяльності, ї̈ вплив на емоційно-вольову сфреру особистості. Виділено основні показники емоційно-рефрлексивного критерію: емоційне ставлення до етнокультури сучасності та усвідомлення емоційної реакції під час використання різних етноформ; артистизм у виконанні, виразність сценічного втілення вокального твору, образу (відповідність міміки, жестів художньому змісту твору; музично-виконавський ентузіазм). Оцінно-результативний критерій зумовлює здатність адекватно оцінювати результати роботи майбутніх учителів музичного мистецтва з етнокультурної діяльності; прагнення їх до самовдосконалення. Відповідно до описаного критерію виділено основні його показники: удосконалення етнокультурних знань, умінь і навичок щодо роботи з майбутніми вчителями музичного мистецтва під час організації різноманітних етнокультурних свят, фрлешмобів, майстер-шеорів, етноярмарок та інших.
\end{abstract}

Ключові слова: критерії, показники, етнокультурна компетентність, учителі музичного мистецтва, сформованість етнокультурної компетентності.

The meaning content of criteria and indicators of the formation of future music art teachers' ethnocultural competence has been justified in the article. It has been stated that the motivationalvalue criterion is characterized by the presence of the future music art teachers' desire to acquire professional and ethno-cultural knowledge, skills and habits that ensure the further successful ethno-cultural activity in practicing with students. The main indicators of this criterion have been highlighted: the desire to acquire ethno-culture, skills and habits of using new ethno-cultural samples; possession of ethno-cultural competence for self-improvement and self-expression in the future professional activity. The cognitivecreative criterion determines the future art music teacher's ability to creative communication with ethno-cultural art and deeply individual vision of the artistic world. The indicators of the presented criterion: completeness of special knowledge: general and ethno-cultural (features, customs, traditions, rituals, beliefs, values and convictions, similarities and differences between cultures of different ethno-regions); the formation of the future music art teachers' ethno-cultural qualities. The emotional-reflexive criterion characterizes the essential feature which allows measuring the emotional component of pedagogical effect of ethno-cultural activity, its influence on the emotional-volitional sphere of personality. The main indicators of emotional-reflexive criterion have been highlighted: emotional attitude to the nowadays ethno-culture and awareness of emotional reaction when using different ethno-forms; artistry in performance, expressiveness of the stage embodiment of a vocal work, image (correspondence of facial expressions and gestures to the artistic content of the work; musical-performing enthusiasm). The evaluation-productive criterion determines the ability to adequate evaluating the results of the future music art teachers' ethnocultural activity; their desire for self-improvement. According to the above described criterion, its main indicators are: improvement of ethno-cultural knowledge, skills and habits as for working with future music art teachers when organizing various ethno-cultural holidays, flash mobs, master-chefs, ethno-fairs, etc.

Key words: criteria, indicators, ethno-cultural competence, music art teachers, formation of ethno-cultural competence.

імені Тараса Шевченка

Постановка проблеми в загальному вигляді. Становлення нової освітньої парадигми на теренах української освіти зумовлено не тільки глибокими соціально-економічними перетвореннями, але й інтенсивним розвитком сучасних теоретико-методологічних підходів до процесу професійної підготовки майбутнього вчителя, застосуванням інноваційних навчальних і куль- турних технологій, впровадженням якісно нових, дієвих моделей, спрямованих на фрормування загальнокультурних компетентностей майбутніх учителів музичного мистецтва. Та, на жаль, можна говорити, що ідея орормування етнокультурної компетентності майбутніх учителів музичного мистецтва в системі вищої освіти ще не отримала осмислення свого актуального стану та не набули 
виокремлення критеріальні характеристики процесу її фрормування.

Аналіз останніх досліджень і публікацій засвідчив, що вивченню проблеми виокремлення критеріїв профресійної компетентності приділяють увагу вчені - І. Бех, І. Зязюн, В. Крижко, А. Маркова, І. Міщенко, Є. Павлютенко, Н. Кузьміна, М. Сідун, а критерії етнокультурної компетентності мають висвітлення у працях Лу Лу, О. Міланової, С. Сєрякової та інших.

Виділення не вирішених раніше частин загальної проблеми. Незважаючи на наявність значної кількості наукових робіт із проблеми компетентності педагогів, малодослідженим, за деякими винятками, залишаються питання фрормування етнокультурної компетентності майбутніх учителів музичного мистецтва, зокрема - сорормованості її критеріїв і показників. Це засвідчує необхідність розгляду сучасної наукової літератури, їїаналізу, що слугуватиме покращенню професійно-педагогічної підготовки майбутніх учителів музичного мистецтва та їхньому подальшому фраховому зростанню.

Мета статті полягає у визначенні критеріїв і показників сорормованості етнокультурної компетентності майбутніх учителів музичного мистецтва.

Виклад основного матеріалу. Зауважимо, що для визначення критеріїв етнокультурної компетентності ми спирались на системне розуміння компетентності, базові поняття фрормування етнокультурної компетентності майбутніх учителів музичногомистецтва, процесірезультатнавчальнопізнавальної діяльності. Для розуміння результативного продукту фрормування етнокультурної компетентності майбутніх учителів музичного мистецтва вважаємо за необхідне виділити такі критерії: мотиваційно-ціннісний, когнітивно-креативний, емоційно-рефлексивний, оцінно-результативний.

Визначаючи критерії етнокультурної компетентності майбутніх учителів музичного мистецтва, ми зважали на те, що: по-перше, процес формування дослідженої компетентності здійснюється у взаємозв'язку, цілісності та взаємовпливі особистості майбутнього вчителя музичного мистецтва, навчальної діяльності, життєвих подій та етнокультурних ситуацій; по-друге, доцільно взяти до уваги сутнісну характеристику та сендвічмодель етнокультурної компетентності майбутніх учителів музичного мистецтва; по-mpemє, необхідно враховувати роль і місце зазначеної компетентності в структурі професійної діяльності, i, по-четверте, аналіз критеріїв повинен виявити ступінь розвитку тої чи іншої площини етнокультурної компетентності майбутніх учителів музичного мистецтва.

Мотиваційно-ціннісний критерій сорормованості етнокультурної компетентності майбутніх учителів музичного мистецтва визначає сукупність мотивів, потреб і цінностей, які спонукають майбутнього вчителя музичного мистецтва до фрормування етнокультурної компетентності. Він припускає наявність інтересу та $є$ постійним спонукальним механізмом, що характеризує потребу майбутнього вчителя в знаннях, в оволодінні ефективними способами організації професійної діяльності. Мотиваційно-ціннісний критерій включає мотиви, потреби та цінності щодо вивчення етнокультурної компетентності матеріальними та нематеріальними засобами, спрямовані на передачу етнокультурних знань і розвиток особистості майбутнього вчителя музичного мистецтва.

У контексті визначеної проблеми вагомим $\epsilon$ міркування Л. Данильчук, яка зазначає, що мотив складне утворення, яке погоджує різні види спонукань: потреби, прагнення, цілі, установки, ідеали [2, с. 321].

Важливим для етнокультурної компетентності $€$ твердження А. Маслоу про повагу, а саме до сім'ї, родини, традицій, звичаїв, вірувань та їх використання у різних етнорегіонах.

У контексті представленого критерію ми розглянемо поняття «цінність», яке німецький фрілоcoфр Р. Лотце трактував як «категоріальний сенс» $\mathrm{i}$ застосував як одну з визначальних характеристик цінностей (зокрема, в етичних, естетичних концепціях) поняття «значення»» [4]. Цінністю $є$ все, що для людини значуще, має особистісний або суспільний смисл.

У зазначеній проблемі цінності відображають повагу до етнічного населення, що визначається із визнання їхньої цінності; етнічне населення унікальна соціальна група, яке реалізує свою унікальність через інші покоління і яке залежить від них у розвитку своєї унікальності; етнічному населенню притаманна здатність до змін, збагачення знань українських традицій, які належать певній етнічній групі, що є важливим для формування етнокультурної компетентності майбутніх учителів музичного мистецтва.

Як зазначалося попередньо, мотиваційно-ціннісний критерій у своїх працях обґрунтовували О. Гуренко, А. Коваленко, І. Міщенко, М. Сідун та інші вчені, за допомогою якого можна визначити значущість українського народного мистецтва як підгрунтя національної культури, що $є$, у свою чергу, невіддільною частиною для фрормування етнокультурної компетентності майбутніх учителів музичного мистецтва.

Виділимо основні показники мотиваційно-ціннісного критерію сорормованості етнокультурної компетентності майбутніх учителів музичного мистецтва: значущість етнокультурних знань, умінь і навичок та застосування їх у майбутній професійній діяльності; оволодіння творчими уміннями та навичками роботи в етнокультурному середовищі; створення умов для подолання труднощів в організації професійної діяльності. 
Мотиваційно-ціннісний критерій характеризується наявністю у майбутніх учителів музичного мистецтва прагнення до опанування професійними та етнокультурними знаннями, уміннями і навичками, що забезпечують подальшу успішну етнокультурну діяльність у практиці з учнівським колективом. Цей критерій передбачає розвиток у майбутніх учителів музичного мистецтва інтересу до традицій, обрядів і звичаїв українського народу різних етнічних груп, фрормування стійкої потреби у їх вивченні для майбутньої професійної діяльності.

Когнітивно-креативний критерій характеризується повнотою й дієвістю знань у процесі виконання різних видів професійної діяльності, які відрізняються від аналогічних новизною підходу, творчим рішенням. Окрім того, майбутній учитель музичного мистецтва має володіти однаково на високому рівні знаннями як теоретичного, так і практичного характеру, оскільки теоретичні знання є підґрунтям для реалізації етнокультурної компетентності, а без практичних знань неможлива професійна етнокультурна діяльність.

Під когнітивним критерієм А. Лутошкін розуміє сукупність відомостей у галузі організаторської роботи, розуміння цілей, завдань і правил діяльності, знання особливостей особистості й колективу [3, с. 15-16].

Когнітивний критерій у своїх працях використовували Н. Білоцерківська, С. Бунін, Лу Лу, О. Міланова, С. Серякова, Н. Сидорчук, Н. Якса та інші вчені, які вважали цей критерій рівнем сорормованості знань, який є одним із найважливіших критеріїв для рівня сфрормованості етнокультурної компетентності майбутніх учителів музичного мистецтва.

Вчена Н. Сидорчук для вдосконалення змісту теоретичних (педагогічних) знань у когнітивному критерії поділила їх на три блоки: блок базових педагогічних знань; блокпрактичнихпедагогічних знань; блок технологічних знань [5, с. 378-379].

Поділяючи міркування вченої, основу цих трьох блоків окресленої проблеми ми наповнили фрормами (традиційними - лекціями, практичними, самостійними та індивідуальними заняттями; інноваційними етноформами - етнофотовиставками (етнофотоколажами), фрлешмобами, етноярмарками, майстер-шефрами, етноквестами, модними фолкфестами, евентформами, етнофорумами) та методами (класичними - методами стимулювання і мотивації навчально-пізнавальної діяльності; методами організації і здійснення навчальнопізнавальної діяльності; методами контролю і самоконтролю за ефрективністю навчально-пізнавальної діяльності; спеціальними - етнокейсами, інтерв'ю, етнографрічним методом, «рівний - рівному», етнопроєктом). За допомогою зазначених форм і методів організації навчальної діяльності та застосування їх у когнітивному критерії майбутні вчителі музичного мистецтва глибше пізнають етнокультурну компетентність, її роль у житті населення різних етнорегіонів, використовують на практиці, яка сприятиме передачі звичаїв і традицій із покоління в покоління.

На часі можна говорити про сорормовану традицію розуміння креативності як здатності, що відбиває глибинну властивість індивідів створювати оригінальні цінності, приймати нестандартні рішення, виходити за межі відомого; як інтегральної властивості особистості, що втілює їі творчі можливості.

Креативність у своїх працях розглядали Я. Карлінська, Лу Лу, Т. Поштарьова, А. Чернишова, які стверджували, що це здатність створення чогось нового чи відродження минулого, в нашому випадку - традицій, звичаїв, обрядів, вірувань, яке відрізняється від іншого нестандартним та унікальним рішенням, наприклад, ілюстрація їх у майстер-шефрах, етноквестах, етносрорумах та інше.

Виділимо основні показники когнітивно-креативного критерію сорормованості етнокультурної компетентності майбутніх учителів музичного мистецтва: знання про сутність і зміст етнокультурної компетентності майбутніх учителів музичного мистецтва, способи і фрорми ії̈ передачі; сорормованість педагогічної етнотворчості; здатність творчо виражати певну ідею етноформ; здатність виразно та чітко відтворювати один і той же звичай, обряд залежно від обраного етнорегіону; здатність створювати етнокультурну атмосферу, яка відрізнятиметься від сьогоднішньої.

Когнітивно-креативний критерій - один із найважливіших критеріїв під час оцінки рівня сорормованості етнокультурної компетентності майбутніх учителів музичного мистецтва, що характеризується здатністю майбутнього вчителя музичного мистецтва до творчого спілкування 3 етнокультурним мистецтвом, до глибоко індивідуального бачення художнього світу. Когнітивно-креативний критерій знаходить своє виявлення у спеціальних формах авторської програми, а саме -у флешмобі, етноквестах, етнопроєктах, етнофорумах та інших.

Емоційно-рефрлексивний критерій характеризує сутнісну ознаку, що дає змогу виміряти емоційний складник педагогічного ефекту етнокультурної діяльності, її вплив на емоційновольову сфреру особистості. Значення цього критерію можна пояснити тим, що оцінка результатів навчання має суттєве значення для формування самооцінки майбутніх учителів музичного мистецтва та його особистості загалом. Успішність емоційно-рефлексивного критерію залежить від емоційно-почуттєвого ставлення, усвідомлення відповідних образних етнокультурних уявлень до етнокультури, становлення належного етнокультурного самопочуття. 
Емоції (від фpp. emotion - «хвилювання», «збудження») - складний стан організму, що припускає тілесні зміни поширеного характеру - в диханні, пульсі, залозо-виділеннях тощо - і на ментальному рівні, стан збудження чи хвилювання, що позначається сильними почуттями, і зазвичай імпульсом щодо певної фрорми поведінки. Рефлекс - автоматична цілісна стереотипна реакція організму на певний подразник, на зміни зовнішнього середовища або внутрішнього стану, яка здійснюється за обов'язкової участі центральної нервової системи. Інакше кажучи, для виникнення рефлексу необхідна наявність чутливого нервового закінчення; нервових волокон - для передачі повідомлення, яке несе подразник; органа, що перетворить інформацію в реакцію; i, нарешті, м'язів і залоз для здійснення самої реакції - зазвичай якого-небудь механічного руху [1].

Виділимо основні показники емоційно-рефлексивного критерію сорормованості етнокультурної компетентності майбутніх учителів музичного мистецтва: емоційне ставлення до загальновизнаних етнокультурних цінностей; координування і регулювання етнокультурної діяльності всіх учасників спілкування й вибір адекватних засобів етнокультурного впливу щодо її подальшого стимулювання (взаємооцінка, взаємоконтроль).

Емоційно-рефрлексивний критерій етнокультурної компетентності 3 урахуванням емоцій, почуттів, потреб, інтересів розкриває інтегративні характеристики особистості майбутнього вчителя музичного мистецтва: етична центрація педагогічної дії, емоційно-вольова зрілість. Емоційно-рефрлексивний критерій виявляє здатність майбутніх учителів музичного мистецтва до емоційно-рефрлексивних реакцій, осягнення емоційної сутності твору, вміння контролювати свій емоційний стан під час виступу на сцені, а також спроможність до рефрлексивного осмислення та аналізу власної етнокультурної діяльності.

Оцінно-результативний критерій характеризується відповідною структурою готовності до етнокультурної діяльності та має вміння оцінити її результати. Із цим критерієм тісно взаємопов'язана самоаналітична активність майбутнього вчителя як наявність умінь і навичок самооцінки, самопізнання 3 метою самовиховання активності, схильність до позитивної самоактуалізації та самовдосконалення.

Виділимо основні показники оцінно-результативного критерію: застосовування матеріальних і нематеріальних засобів у навчально-пізнавальній діяльності майбутніх учителів музичного мистецтва під час фрормування етнокультурної компетентності; прояв творчої активності, ініціативи в процесі роботи над етнофотовиставками, етнофотоколажами та етноквестами.
Оцінно-результативний критерій характеризується здатністю адекватно оцінювати результати роботи майбутніх учителів музичного мистецтва 3 етнокультурної діяльності; прагнення їх до самовдосконалення. Цей критерій тісно пов'язаний 3 особистістю майбутнього вчителя музичного мистецтва, його мотивами та системою етнокультурних цінностей, а загалом визначається професійними якостями майбутнього вчителя музичного мистецтва.

Висновки. Отже, ми визначили та охарактеризували критерії й показники сформованості етнокультурної компетентності майбутніх учителів музичного мистецтва: мотиваційно-ціннісний (потреби, мотиви, інтереси, що спонукають майбутніх учителів музичного мистецтва до вивчення етнокультурної компетентності); когнітивно-креативний (профресійні знання - теоретичний тезаурус майбутнього вчителя музичного мистецтва та здатність до творчості в процесі етнокультурної діяльності); емоційно-рефрлексивний (емоційне ставлення, конкретні дії майбутнього учителя під час етнокультурної діяльності); оцінно-результативний (великий обсяг етнокультурних знань і застосування їх на практиці).

Перспективами подальшого дослідження вважаємо такі: вивчення реального стану сорормованості етнокультурної компетентності майбутніх учителів музичного мистецтва, визначення та опис взаємозалежних і послідовних рівнів сорормованості етнокультурної компетентності майбутніх учителів музичного мистецтва на основі аналізу попередніх напрацювань.

\section{БІБЛІОГРАФІЧНИЙ СПИСОК:}

1. Вікіпедія. URL: http://www.wikipedia.org (дата звернення: 16.03.2017).

2. Данильчук Л.О. Соціальна профілактика торгівлі людьми засобами інформаційно-комунікативних технологій: теорія і методика : монографія. Хмельницький : ФОП Цюпак А.А., 2014. 496 с. С. 321.

3. Лутошкин А.Н. Как вести за собой: Старшеклассникам об основах орг. работы / под ред. Б.3. Вульфова; 3-е изд., перераб. и доп. Москва : Просвещение, 1986. С. 15-16.

4. Пазенок В.С. Філософія: навч. посіб. для вищ. навч. закл. Київ : Академвидав, 2008. 280 с.

5. Сидорчук Н.Г. Профресійно-педагогічна підготовка студентів університетів у контексті єдиного європейського освітнього простору: історико-педагогічний аспект : монографрія / за ред. О.А. Дубасенюк. Житомир : Вид-во ЖДУ ім. І. Франка, 2014. 608 с.

6. Сідун М.М. Критерії та рівні сорормованості просресійної компетентності майбутнього вчителя іноземної мови початкової школи. URL: http://naub.oa.edu.ua/2013/kryteriji-ta-rivnisformovanosti-profesijnoji-kompetentnosti-majbutnohovchytelya-inozemnoji-movy-pochatkovoji-shkoly/ (дата звернення: 14.03.2017). 